\title{
A study on correlation between bleeding pattern and histopathological findings of endometrium among perimenopausal women
}

\author{
Radha Nair ${ }^{1 *}$, Mallikarjuna M. ${ }^{2}$
}

\begin{abstract}
${ }^{1}$ Department of Obstetrics \& Gynaecology, Kerala Medical College, Mangod, Cherupulassery, Palakkad, Kerala, India
${ }^{2}$ Department of Obstetrics \& Gynaecology, Mount Zion Medical College, Chayalode, Adoor, Kerala, India
\end{abstract}

Received: 28 October 2015

Accepted: 14 November 2015

\section{*Correspondence: \\ Dr. Radha Nair, \\ E-mail: ramspam@gmail.com}

Copyright: (c) the author(s), publisher and licensee Medip Academy. This is an open-access article distributed under the terms of the Creative Commons Attribution Non-Commercial License, which permits unrestricted non-commercial use, distribution, and reproduction in any medium, provided the original work is properly cited.

\begin{abstract}
Background: During climacteric, ovarian activity declines. Initially, ovulation fails, no corpus luteum forms, and no progesterone are secreted by the ovary. Therefore the premenopausal menstrual cycles are shortened, often anovulatory and irregular. The irregularity in menstrual cycle during perimenopause can be due to anovulation or to irregular maturation of follicles.

Methods: The endometrial samples (endometrial curettage/ biopsy and hysterectomy specimens) sent to pathology laboratory were analyzed. These specimens are fixed in $10 \%$ formalin and gross morphology was recorded. Endometrial samples were totally embedded and representative bits are taken from hysterectomy specimens. These bits were placed in cassettes and kept in fixative and processed in the automatic tissue processor. Paraffin tissue blocks were prepared and 3-4 micrometer thick sections were cut and stained with routine haematoxylin and eosin. A detailed histological study was carried out and the findings were noted.

Results: Among total study subjects, $62 \%$ of patient's endometrium was in proliferative phase, $26 \%$ of patient's endometrium was in secretory phase, $6 \%$ of patient's endometrium was in cystoglandular hyperplasia. Dysplasia with atypical changes was found in $2 \%$ of patients. Adenomatous polyp was found in $2 \%$ of patients. Simple hyperplasia was found in $2 \%$ of patients.
\end{abstract}

Conclusions: Patients with abnormal uterine bleeding should always be subjected to histopathological investigation.

Keywords: Abnormal uterine bleeding, Perimenopausal, Histopathological examination

\section{INTRODUCTION}

The endometrium is uniquely endowed throughout the female reproductive lifespan with complex regular cycle of periodic proliferation, differentiation, breakdown and regeneration. ${ }^{1}$ Menstruation is the cyclic uterine bleeding experienced by almost all women of reproductive age.

Normal menstruation is defined as "the bleeding from secretory endometrium associated with an ovulatory cycle, not exceeding a length of five days". Any bleeding not fulfilling these criteria is referred to as abnormal uterine bleeding. ${ }^{2}$ Abnormal uterine bleeding is a very common gynecological condition that affects all age groups. One third of patients attending gynaecology OPD present with complaints of abnormal uterine bleeding. ${ }^{3}$ Bleeding is said to be abnormal when the pattern is irregular, abnormal duration (>7 days), or menorrhagia or abnormal amount (>80 ml/menses). ${ }^{4}$

During climacteric, ovarian activity declines. Initially, ovulation fails, no corpus luteum forms, and no progesterone are secreted by the ovary. Therefore the premenopausal menstrual cycles are shortened, often anovulatory and irregular. The irregularity in menstrual cycle during perimenopause can be due to anovulation or to irregular maturation of follicles. ${ }^{5}$ The increased risk of endometrial hyperplasia and endometrial carcinoma is 
more evident in peri-menopausal and post-menopausal women with abnormal uterine bleeding. ${ }^{6}$ The varied pattern of endometrial changes attracted our attention in peri-menopausal and post-menopausal age so to study them in detail with the help of available clinical data.

The endometrial sampling is chosen to evaluate abnormal uterine bleeding because it has several advantages over other diagnostic methods. The hormonal assay is very expensive and laboratories with hormonal assay are not available in rural areas.

Ultrasonography clearly depicts the uterine contour and the status of the ovary, but fails to provide adequate information regarding the endometrium, except in atrophy and hyperplasia. Other investigations like hysteroscopy and hysterosalpingography are mainly helpful in diagnosing organic pathology. ${ }^{7}$ Endometrial curettage is relatively inexpensive and accurate as an outpatient procedure. The only disadvantage of endometrial biopsy is that, it is an invasive procedure.

An understanding of the varieties in the normal morphological appearance of the endometrium provides an essential background for the evaluation of endometrial pathology.

\section{METHODS}

The study population consisted of patients in the perimenopausal age group ( $45 \pm 5$ years) presenting with abnormal uterine bleeding.

\section{Sample size}

All patients in the perimenopausal age group $(45 \pm 5$ years) with symptoms of abnormal uterine bleeding presenting at department of OBG, Tertiary care centre during the study period were included in the study

Sample size is based on level of precision; precision consists of significance level and allowable error. In this study $5 \%$ significance and $20 \%$ allowable error is considered. Totally 50 study subjects were included in the study as this number of patients attended hospital during the study period

\section{Method of sampling}

No sampling method adopted as all the study subject fitting to inclusion criteria were considered

\section{Method of collection of data}

Study tool

Pre tested semi structured Questionnaire. The Questionnaire was presented in the Department for critical review, following which necessary changes were made in the Questionnaire.
Data was collected using Pre tested semi structured Questionnaire which was filed by the investigator. The endometrial samples (endometrial curettage/ biopsy and hysterectomy specimens) sent to pathology laboratory were analysed.

These specimens are fixed in $10 \%$ formalin and gross morphology was recorded. Endometrial samples were hysterectomy specimens. These bits were placed in cassettes and kept in fixative and processed in the totally embedded and representative bits are taken from automatic tissue processor.

Paraffin tissue blocks were prepared and 3-4 micrometre thick sections were cut and stained with routine haematoxylin and eosin. A detailed histological study was carried out and the findings were noted. Statistical analysis was done.

\section{Statistical tests used}

1. Proportion

2. Mean

3. Standard deviation

4. Chi square test

\section{Data entry and analysis}

Using Micro soft excel and Statistical package for social sciences

\section{Ethical consideration}

The protocol designed for the present study was submitted to the Ethical committee, after getting clearance from Research committee. Verbal consent was also taken and Confidentiality of the data is maintained.

\section{RESULTS}

Table 1: Distribution based on findings on histopathological examination.

\begin{tabular}{|lll|}
\hline HPE findings & Frequency & $\%$ \\
\hline Proliferative phase & 31 & 62.0 \\
\hline Secretory phase & 13 & 26.0 \\
\hline Cystoglandular hyperplasia & 03 & 06.0 \\
\hline Dysplasia with atypical changes & 01 & 02.0 \\
\hline Adenomatous polyp & 01 & 02.0 \\
\hline Simple hyperplasia & 01 & 02.0 \\
\hline Total & 50 & 100.0 \\
\hline
\end{tabular}

Among total study subjects, 62\% of patient's endometrium was in proliferative phase, $26 \%$ of patient's endometrium was in secretory phase, $6 \%$ of patient's endometrium was in Cystoglandular hyperplasia. Dysplasia with atypical changes was found in $2 \%$ of patients, adenomatous polyp was found in $2 \%$ of patients, simple hyperplasia was found in $2 \%$ of patients. 
Table 2: Relation between menorrhagia and findings on histopathological examination.

\begin{tabular}{|llll|}
\hline \multirow{2}{*}{ HPE findings } & \multicolumn{2}{l}{ Yenorrhagia } & Total \\
\hline $\begin{array}{l}\text { Proliferative } \\
\text { phase }\end{array}$ & $\begin{array}{l}21 \\
(65.6 \%)\end{array}$ & $10(55.5 \%)$ & $\begin{array}{l}31 \\
(62 \%)\end{array}$ \\
\hline $\begin{array}{l}\text { Secretory } \\
\text { phase }\end{array}$ & $\begin{array}{l}09 \\
(28.1 \%)\end{array}$ & $04(22.2 \%)$ & $\begin{array}{l}13 \\
(26 \%)\end{array}$ \\
\hline $\begin{array}{l}\text { Cystoglandular } \\
\text { hyperplasia }\end{array}$ & $\begin{array}{l}01 \\
(03.1 \%)\end{array}$ & $02(11.1 \%)$ & $\begin{array}{l}03 \\
(06 \%)\end{array}$ \\
\hline $\begin{array}{l}\text { Dysplasia with } \\
\text { atypical } \\
\text { changes }\end{array}$ & 00 & $01(05.5 \%)$ & $\begin{array}{l}01 \\
(02 \%)\end{array}$ \\
\hline $\begin{array}{l}\text { Adenomatous } \\
\text { polyp }\end{array}$ & 00 & $01(05.5 \%)$ & $\begin{array}{l}01 \\
(02 \%)\end{array}$ \\
\hline $\begin{array}{l}\text { Simple } \\
\text { hyperplasia }\end{array}$ & \begin{tabular}{l}
$(03.1 \%)$ \\
\hline Total
\end{tabular} & 00 & $\begin{array}{l}01 \\
(02 \%)\end{array}$ \\
\hline
\end{tabular}

P value: 0.001

Among patients without history of menorrhagia, the more common endometrium finding was proliferative phase (55.5\%) followed by secretory phases (22.2\%). Cystoglandular hyperplasia was found in $11.1 \%$ of patients and adenomatous polyp was found in $5.5 \%$ of patients. This relation is found to be statistically significant.

Table 3: Relation between metrorrhagia and findings on histopathological examination.

\begin{tabular}{|c|c|c|c|}
\hline \multirow{2}{*}{ HPE findings } & \multicolumn{2}{|c|}{ Metrorrhagia } & \multirow{2}{*}{ Total } \\
\hline & Yes & No & \\
\hline $\begin{array}{l}\text { Proliferative } \\
\text { phase }\end{array}$ & $05(55.5 \%)$ & $26(63.4 \%)$ & $\begin{array}{l}31 \\
(62 \%)\end{array}$ \\
\hline $\begin{array}{l}\text { Secretory } \\
\text { phase }\end{array}$ & $03(33.3 \%)$ & $10(24.3 \%)$ & $\begin{array}{l}13 \\
(26 \%)\end{array}$ \\
\hline $\begin{array}{l}\text { Cystoglandular } \\
\text { hyperplasia }\end{array}$ & $01(11.1 \%)$ & $02(04.8 \%)$ & $\begin{array}{l}03 \\
(06 \%)\end{array}$ \\
\hline $\begin{array}{l}\text { Dysplasia with } \\
\text { atypical } \\
\text { changes }\end{array}$ & 00 & $01(02.4 \%)$ & $\begin{array}{l}01 \\
(02 \%)\end{array}$ \\
\hline $\begin{array}{l}\text { Adenomatous } \\
\text { polyp }\end{array}$ & 00 & $01(02.4 \%)$ & $\begin{array}{l}01 \\
(02 \%)\end{array}$ \\
\hline $\begin{array}{l}\text { Simple } \\
\text { hyperplasia }\end{array}$ & 00 & $01(02.4 \%)$ & $\begin{array}{l}01 \\
(02 \%)\end{array}$ \\
\hline Total & $09(100 \%)$ & $41(100 \%)$ & $\begin{array}{l}50 \\
(100 \%)\end{array}$ \\
\hline
\end{tabular}

$P$ value: 0.003

Proliferative phase was more commonly found in patients without h/o metrorrhagia $(63.4 \%)$ compared to patients with h/o metrorrhagia (55.5\%).
Secretary phase was more commonly found in patients with h/o metrorrhagia (33.3\%) compared to patients without h/o metrorrhagia (24.3\%).

Adenomatous polyp, simple hyperplasia and dysplasia were found in patients without h/o metrorrhagia. The relation between metrorrhagia and histopathological findings in this study is found to be statistically significant.

Table 4: Relation between menometrorrhagia and findings on histopathological examination.

\begin{tabular}{|c|c|c|c|}
\hline \multirow{2}{*}{ HPE findings } & \multicolumn{2}{|c|}{ Menometrorrhagia } & \multirow{2}{*}{ Total } \\
\hline & Yes & No & \\
\hline $\begin{array}{l}\text { Proliferative } \\
\text { phase }\end{array}$ & $01(25 \%)$ & $30(65.2 \%)$ & $\begin{array}{l}31 \\
(62 \%)\end{array}$ \\
\hline $\begin{array}{l}\text { Secretory } \\
\text { phase }\end{array}$ & 00 & $13(28.2 \%)$ & $\begin{array}{l}13 \\
(26 \%)\end{array}$ \\
\hline $\begin{array}{l}\text { Cystoglandular } \\
\text { hyperplasia }\end{array}$ & $01(25 \%)$ & $02(04.3 \%)$ & $\begin{array}{l}03 \\
(06 \%)\end{array}$ \\
\hline $\begin{array}{l}\text { Dysplasia with } \\
\text { atypical } \\
\text { changes }\end{array}$ & $01(25 \%)$ & 00 & $\begin{array}{l}01 \\
(02 \%)\end{array}$ \\
\hline $\begin{array}{l}\text { Adenomatous } \\
\text { polyp }\end{array}$ & $01(25 \%)$ & 00 & $\begin{array}{l}01 \\
(02 \%)\end{array}$ \\
\hline $\begin{array}{l}\text { Simple } \\
\text { hyperplasia }\end{array}$ & 00 & $01(02.2 \%)$ & $\begin{array}{l}01 \\
(02 \%)\end{array}$ \\
\hline Total & $04(100 \%)$ & $46(100 \%)$ & $\begin{array}{l}50 \\
(100 \%)\end{array}$ \\
\hline
\end{tabular}

P value: 0.01

Table 5: Relation between polymenorrhoea and findings on histopathological examination.

\begin{tabular}{|c|c|c|c|}
\hline \multirow{2}{*}{ HPE findings } & \multicolumn{2}{|c|}{ Polymenorrhoea } & \multirow{2}{*}{ Total } \\
\hline & Yes & No & \\
\hline $\begin{array}{l}\text { Proliferative } \\
\text { phase }\end{array}$ & $08(57.1 \%)$ & $23(63.8 \%)$ & $\begin{array}{l}31 \\
(62 \%)\end{array}$ \\
\hline $\begin{array}{l}\text { Secretory } \\
\text { phase }\end{array}$ & $03(21.4 \%)$ & $10(27.7 \%)$ & $\begin{array}{l}13 \\
(26 \%)\end{array}$ \\
\hline $\begin{array}{l}\text { Cystoglandular } \\
\text { hyperplasia }\end{array}$ & $01(07.1 \%)$ & $02(05.5 \%)$ & $\begin{array}{l}03 \\
(06 \%)\end{array}$ \\
\hline $\begin{array}{l}\text { Dysplasia with } \\
\text { atypical } \\
\text { changes }\end{array}$ & 00 & $01(02.7 \%)$ & $\begin{array}{l}01 \\
(02 \%)\end{array}$ \\
\hline $\begin{array}{l}\text { Adenomatous } \\
\text { polyp }\end{array}$ & $01(07.1 \%)$ & 00 & $\begin{array}{l}01 \\
(02 \%)\end{array}$ \\
\hline $\begin{array}{l}\text { Simple } \\
\text { hyperplasia }\end{array}$ & $01(07.1 \%)$ & 00 & $\begin{array}{l}01 \\
(02 \%)\end{array}$ \\
\hline Total & $14(100 \%)$ & $36(100 \%)$ & $\begin{array}{l}50 \\
(100 \%)\end{array}$ \\
\hline
\end{tabular}

$P$ value: 0.01

Proliferative phase was more commonly found in patients without h/o menometrorrhagia $(65.2 \%)$ compared to patients with h/o menometrorrhagia (25\%). 
Secretary phase was more commonly found in patients without h/o menometrorrhagia (28.2\%) compared to patients without h/o menometrorrhagia $(0 \%)$.

Adenomatous polyp and dysplasia were found in patients with h/o menometrorrhagia. The relation between menometrorrhagia and histopathological findings in this study is found to be statistically significant.

Proliferative phase was more commonly found in patients without h/o polymenorrhoea $(63.8 \%)$ compared to patients with h/o polymenorrhoea (57.1\%). Secretary phase was more commonly found in patients without $\mathrm{h} / \mathrm{o}$ polymenorrhoea $(27.7 \%)$ compared to patients without h/o polymenorrhoea (21.4\%). Adenomatous polyp, Simple hyperplasia was found in patients with h/o polymenorrhoea. Dysplasia was found in patients without h/o polymenorrhoea. The relation between polymenorrhoea and histopathological findings in this study is found to be statistically significant.

Table 6: Relation between present cycles and findings on histopathological examination.

\begin{tabular}{|llll|}
\hline HPE findings & \multicolumn{2}{l}{ Present cycles } & Total \\
\cline { 2 - 4 } & Regular & Irregular & \\
\hline $\begin{array}{l}\text { Proliferative } \\
\text { phase }\end{array}$ & $\begin{array}{l}26 \\
(68.4 \%)\end{array}$ & $05(41.6 \%)$ & $\begin{array}{l}31 \\
(62 \%)\end{array}$ \\
\hline Secretory phase & $\begin{array}{l}10 \\
(26.3 \%)\end{array}$ & $03(25.0 \%)$ & $\begin{array}{l}13 \\
(26 \%)\end{array}$ \\
\hline $\begin{array}{l}\text { Cystoglandular } \\
\text { hyperplasia }\end{array}$ & $\begin{array}{l}01 \\
(02.6 \%)\end{array}$ & $02(16.6 \%)$ & $\begin{array}{l}03 \\
(06 \%)\end{array}$ \\
\hline $\begin{array}{l}\text { Dysplasia with } \\
\text { atypical } \\
\text { changes }\end{array}$ & 00 & $01(08.3 \%)$ & $\begin{array}{l}01 \\
(02 \%)\end{array}$ \\
\hline $\begin{array}{l}\text { Adenomatous } \\
\text { polyp }\end{array}$ & 00 & $01(08.3 \%)$ & $\begin{array}{l}01 \\
(02 \%)\end{array}$ \\
\hline $\begin{array}{l}\text { Simple } \\
\text { hyperplasia }\end{array}$ & $\begin{array}{l}01 \\
(02.6 \%)\end{array}$ & 00 & $\begin{array}{l}01 \\
(02 \%)\end{array}$ \\
\hline Total & $38(100 \%)$ & $12(100 \%)$ & $\begin{array}{l}50 \\
(100 \%)\end{array}$ \\
\hline
\end{tabular}

P value: 0.34

Among patient with irregular cycles, $41.6 \%$ of patients were in proliferative phase, $25 \%$ were in secretory phase, $16.6 \%$ of patients had cystoglandular hyperplasia, and $8.3 \%$ of patients had adenomatous polyp and simple hyperplasia.

\section{DISCUSSION}

In the present study proliferative phase $(35 \%)$ was found to be most common histologic pattern followed by secretory phase $(26.5 \%)$, simple hyperplasia without atypia $(24 \%)$, atrophic endometrium $(3.5 \%)$, disordered proliferative (3\%), mixed endometrium (3\%), endometrial polyp (2\%), endometrial adenocarcinoma $(1 \%)$ and endometrial stromal sarcoma $(0.5 \%)$. In the study done by Sadia Khan proliferative phase was most common histological pattern followed by secretory phase, simple hyperplasia without atypia, complex hyperplasia without atypia, atrophic endometrium, endometrial polyp, endometritis and endometrial adenocarcinoma in that order. ${ }^{8}$

Table 7: Comparative study of incidence of disordered proliferative endometrium in AUB.

\begin{tabular}{|lll|l|}
\hline Authors & Year & Number & Percentage \\
\hline Azim P $^{10}$ & 2011 & 128 & $5.4 \%$ \\
\hline Mirza T $^{11}$ & 2012 & 1000 & $23 \%$ \\
\hline Bhatta S $^{12}$ & 2012 & 122 & $6.56 \%$ \\
\hline $\begin{array}{l}\text { Present } \\
\text { study }\end{array}$ & 2013 & 200 & $8 \%$ \\
\hline
\end{tabular}

Majority of the studies including the present study indicate that, the incidence of hyperplasia in AUB ranges from $19.4 \%$ to $31.25 \%$ whereas, a few other studies reported a higher incidence at $52 \%$ to $62 \%$ range while the lowest incidence $7 \%$ was reported by Sanyal. ${ }^{9}$

In the present study, the two important observations were made regarding endometrial hyperplasia in AUB and they are:

1. Endometrial hyperplasia was highest in the age group of 41-50 years.

2. It was highest in patients with history of heavy menstrual bleeding.

Mirza $\mathrm{T}$ noted maximum number of disordered proliferative endometrium accounting for the $23 \%$. In the present study, the incidence of disordered proliferative endometrium was $8 \%$ which was close to the findings observed by Azim P. ${ }^{10,11}$

\section{CONCLUSION}

There is positive correlation between presenting bleeding pattern and abnormal findings of endometrium in patients with abnormal uterine bleeding.

\section{Funding: No funding sources}

Conflict of interest: None declared

Ethical approval: The study was approved by the Institutional Ethics Committee

\section{REFERENCES}

1. Tavassoli FA, Devilee P. Pathology and genetics of tumours of the breast and female genital organs. Lyon France: IARC. Tumours of the uterine corpus. In: WHO classifications of tumours. 2003: 221-232.

2. Rosai RJ, Ackerman's surgical pathology. New Delhi: Elseiver, A division of Reed Elsevier, India Private limited. Female reproductive system - Uterus - corpus. In: Rosai J Ed. 2004;4(9):1569-635.

3. Awwad JT, Toth TL, Schiff I. Abnormal Uterine Bleeding in the Perimenopause. International Journal 
of Fertility \& Menopausal Studies. 1993;38(5):2619.

4. Speroff L, Fritz MA. In: Clinical gynaecologic endocrinology and infertility. 7th edition. Jaypee Brothers Med Publishers (P) Ltd; 2005. Menopause and the peri-menopausal transition. 2005;621-88.

5. Padubidri VG, Daftary SN. Howkins and Bourne Shaw's Textbook of Gynaecology. Noida: Elsevier, A division of Reed Elsevier India Private Limited; 2008. Perimenopause, Menopause, Premature Menopause and Post-menopausal Bleeding. In: Padubidri VG, Daftary SN. 2008;14:52-62.

6. Kumar A, Mittal S. Endometrial sampling: How? \& why? Obs and Gynae Today. 2007;12(6):284-7.

7. Gusberg SB, Kaplan AL. Precursors of Corpus Cancer-4, Adenomatous Hyperplasia as stage 0 Carcinoma of Endometrium, American Journal of Obstetrics and Gynaecology. 1963;87(5):662-76.

8. Khan S, Sadia H, Umber A. Histopathological Pattern of Endometrium on Diagnostic D\&C in patients with Abnormal Uterine Bleeding. Annals. 2011;17(2):166-70.
9. Sanyal MK, Sanyal S, Bhattacherjee KK, RoyChoudhuri NN. Clinicopathological study of endometrium: A review of three thousand ninehundred twenty cases in different gynaecologicalabnormalities. J Obstet Gynaecol India. 1981;31(5):816-21.

10. Azim P, Khan MM, Sharif N, Khattak EG. Evaluation of abnormal uterine bleeding on endometrial biopsies. Isra Medical J. 2011;3(3):84-8.

11. Mirza T, Akram S, Mirza A, Aziz S, Mirza T, Mustansar T. Histopathological Pattern of Abnormal Uterine Bleeding in Endometrial Biopsies. J Basic and Applied Sciences. 2012;8:114-7.

12. Al-Neaimy WMT, Ahmed MT, Al-Jawadi SI. Histopathological Interpretation of Abnormal uterine bleeding after the age of 40 year. The Iraqi postgraduate medical journal. 2010;9(3):274-82.

Cite this article as: Nair R, Mallikarjuna M. A study on correlation between bleeding pattern and histopathological findings of endometrium among perimenopausal women. Int J Reprod Contracept Obstet Gynecol 2015;4:1758-62. 